\title{
The Implementation of Blended Learning on Introduction to Accounting 1 Subject
}

\author{
Rita Rahayu ${ }^{1 *}$ Indah Permata Suryani $^{1}$ Efa Yonnedi ${ }^{1}$ \\ ${ }^{1}$ Accounting Department, Universitas Andalas, Sumatera Barat, Indonesia \\ *Corresponding author. Email: ritarahayu@eb.unand.ac.id
}

\begin{abstract}
This study aims to evaluate implementing a blended learning method on the Introduction to Accounting 1 subject. Blended Semester Learning Plan (SLP) has been developed and implemented on this subject since September 2020. Three indicators were used to evaluate the implementation of blended learning on this subject, which are student perception, distribution of assignment score, and the achievement of learning outcomes. Based on online questionnaire that send to the sixteenth students who enrolled in this class, it is found that the method has a positive impact on the increase of student understanding. Then, it is also mentioned by the students that blended learning offers four main benefits, which are easier to understand the topics, easy access to learning material, encourage active learning and increase interactivity. In regard to the distribution of assignment score and the achievement of learning outcomes, this study also found that all of student have high scores, between 70 to 100 .
\end{abstract}

Keyword: Blended learning, Accounting, Implementation

\section{INTRODUCTION}

The Introduction to Accountingl is a compulsory subject for Accounting Study Program students. This subject is one of the core subjects in the financial accounting field and is offered in the first semester. This subject explains the basic concepts of accounting, business process, accounting equations, and explains the accounting cycle for service companies and trading companies. This course is essential because it will be the basis for understanding other courses in accounting.

As this course is offered in the first semester, all of the participants are new students who do not understand accounting, so most of them experience difficulties. Based on observations made over the last few years, their understanding level is still low since their average score is below 70 .

The learning methods that have been applied in the previous semester were face to face lectures. In this method, the lecturer prepared the teaching materials and required students to read and understand the teaching materials before classes. Then, students were asked to do assignments. This method is considered ineffective, mainly because of the face-to-face method that requires students to attend lectures. For students who do not understand or are not present at the time of learning, of course, they will experience difficulties in understanding the lesson.
These difficulties then had an impact on the understanding of the next topic that required prior understanding. As we have known that the materials presented in this course are interrelated material, which means that if students do not understand how to make a journal, they can be sure cannot understand the next material, such as preparing ledgers, and of course, they will not be able to prepare financial reports.

To overcome the face-to-face limitation, Educational literature suggests using a blended learning method by combining traditional face to face lectures with elearning activities. This method provides flexibility for students or lecturers in carrying out the learning process. Therefore, to solve the difficulties that arise in the previous semester, blended learning is applied this semester. The blended learning method has been applied since the beginning of September 2020. This study aims to evaluate the implementation of blended learning in Introduction to Accounting 1 subject.

\subsection{Descriptive of Introduction to Accounting 1 subject}

Introduction to Accounting I is a compulsory subject in the first semester and a core subject in the financial accounting field. This subject defines accounting's nature and purpose and includes measurement of income, underlying assumptions, the flow of funds, and performance analysis. 
After studying this subject, the students should be able (1) to develop a working knowledge of the fundamental terms, definitions, and principles used by accountants in the accounting process and in the preparation of financial statements, (2) to prepare financial statements of services and merchandise company, (3) gain an understanding of a financial statement and its building blocks, (4) communicate the business and accounting elements of a transaction and compare components of the financial statements of one company to another.

Therefore, five Subject Learning Outcome (Capaian Pembelajaran Mata Kuliah / CPMK) of this subject have been defined, which are: (1) Have knowledge of terms, definitions, and basic principles in preparing financial statements (2) Able to compile company financial reports, (3) Able to work in a team, (4) Able to communicate the business and accounting elements of a transaction, and (5) Have high ethics and integrity.

\subsection{The contribution of the Subject to Graduate Learning Outcomes}

Universitas Andalas Accounting Study Program has formulated the graduate profile that relied on its vision and mission. The graduate profiles of this program are "Having strong analytical skills and ability to exercise professional judgments in accounting and related fields by taking into account sustainability and ethic in decision making as well as committed to life-long learning." Based on this profile, it can be seen that there are five attributes of the profiles, which are (1) have strong analytical skills, able to considering principles of (2) sustainability, and (3) ethics in (4) exercising professional judgments, and have a strong commitment to (5) life-long learning.

Then based on the graduates' profiles, The Accounting Study Program has defined 10 Graduate Learning Outcomes (GLO), as follows:

Table 1. Graduate Learning Outcomes

\begin{tabular}{|l|l|c|}
\hline No. & $\begin{array}{c}\text { Domain of } \\
\text { Learning }\end{array}$ & Graduate Learning Outcome (GLO) \\
\hline A. & $\begin{array}{l}\text { Knowledge } \\
\text { Proficiency }\end{array}$ & $\begin{array}{c}\text { 1: Having knowledge and skills in } \\
\text { accounting, assurance, finance, \& } \\
\text { taxation } \\
\text { 2: Having knowledge and skills in } \\
\text { governance, risk \& compliance } \\
\text { (GRC) }\end{array}$ \\
\hline B. & $\begin{array}{l}\text { Work Skill } \\
\text { Capability }\end{array}$ & $\begin{array}{l}\text { 3: Able to apply knowledge and skills in } \\
\text { accounting, assurance, finance, \& } \\
\text { taxation }\end{array}$ \\
& $\begin{array}{l}\text { 4: Able to apply knowledge and skills in } \\
\text { governance, risk \& compliance } \\
\text { (GRC) }\end{array}$ \\
& $\begin{array}{l}\text { 5: Able to utilize information systems and } \\
\text { technology }\end{array}$ \\
\hline C. & Managerial & $\begin{array}{l}\text { 6: Able to exercise professional judgment } \\
\text { 7: Able to work in a team } \\
\text { 8: Having good communication skill, } \\
\text { both oral and written }\end{array}$ \\
\hline D. & $\begin{array}{l}\text { Value And } \\
\text { Attitude }\end{array}$ & $\begin{array}{l}\text { 9: Having a strong character, attitude, and } \\
\text { integrity }\end{array}$ \\
\hline
\end{tabular}

\begin{tabular}{|l|l|l|}
\hline & $\begin{array}{c}\text { 10: Able to adapt current and future } \\
\text { issues in accounting, finance, } \\
\text { assurance, and taxation }\end{array}$ \\
\hline
\end{tabular}

The Introduction to Accounting 1 subject has been designed to contribute to the achievement of GLO. In this regard, the contribution of CPMK Introduction to Accounting I to GLO is as follows:

1. Know terms, definitions, and basic principles in preparing financial reports (GLO A.1, B.1)

2. Able to compile company financial reports (GLO A.1, B.1)

3. Able to work in a team (GLO C.3)

4. Able to communicate the business and accounting elements of a transaction (GLO B.1, C.4)

5. Have high ethics and integrity (GLO D.1)

\section{METHODS}

This study can be categorized as classroom action research. Classroom action research is a form of research conducted in the classroom with specific treatments to improve the learning process to achieve subject learning outcomes. In this regard, the blended learning method is applied to the Introduction to Accounting 1 subject.

The blended learning method is often associated with combining face-to-face traditional to e-learning activities, such as asynchronous work that students can access anywhere (Singh, 2003). Similarly, Graham (2006) revealed that blended learning systems combine face-to- face instruction with computer-mediated instruction. This method is considered an effective way to overcome the weaknesses of the traditional face-toface method.

This study consists of three stages, which are planning, implementation, and evaluation. Each stage is explained below.

\subsection{Stage 1. Planning}

In this stage, team teaching prepared a learning plan for Semester Learning Plan (SLP). In this SLP, the team combines face-to-face teaching methods and asynchronous work called blended SLP. The blended SLP contains detailed information about the description of the subjects, graduate profile, learning objective, learning method, student assessment, course code of conduct, the topic discussed, assignment, student learning outcome, and the contribution of SLP to GLO. Besides, the SLP also explained the media used in the learning process.

As blended learning, this subject combines face to face teaching, synchronous, and asynchronous, using various media, such as zoom meeting, WhatsApp application, e-learning system, and skype meeting. In 
this subject, the asynchronous method is applied by creating videos uploaded on YouTube and uploading learning material in the e-learning system to access these materials anytime and anywhere.

\subsection{Stage 2. Implementation}

In this stage, the blended SLP is implemented. The implementation starts on September 4, 2020, until December 15, 2020. Before implemented, the SLP has been distributed to students through the e-learning system.

\subsection{Stage 3. Evaluation}

To evaluate the implementation of this method, the following indicators are being used as measures, which are: (1) the student perception of this method (2) the distribution of assignment score (3) the achievement of learning outcomes.

\section{RESULT AND DISCUSSION}

Implementing blended learning on the Introductory to Accounting 1 has been started on September 8, 2020, with 16 class participants consisting of 10 women and six men. The schedule for this subject is everyTuesday at $7.30 \mathrm{am}$.

The lecture is conducted using the blended method, combining face-to-face meetings (synchronous) using the zoom meeting application with an asynchronous method. Asynchronous is applied by creating four videos uploaded on YouTube and discussion forum using i-learn and WhatsApp.

The evaluation of this method has been carried out using three indicators as described before, which are (1) the student perception of this method, (2) the distribution of assignment score (3) the achievement of learning outcomes. The following are the results of the evaluation:

\subsection{The Students Perception}

The student perceptions were collected through a questionnaire that was sent in the fifth week of the lecture. In this regard, 16 students participated. Below is the student perception of their preferences for learning methods.

Figures 1. Student Preferences for Learning Method

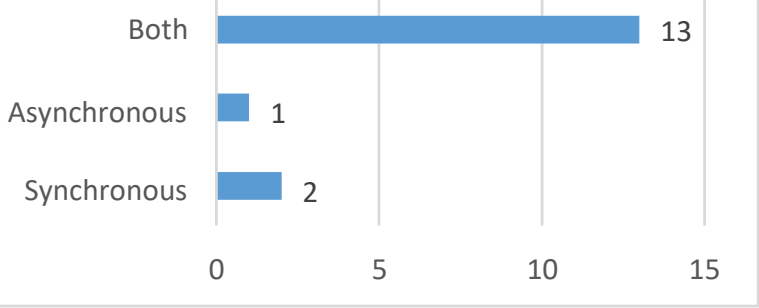

It can be seen from Figure 1 that most of the students, which are 13 students $(81.25 \%)$, prefer to apply the blended method by combining synchronous and asynchronous methods. Simultaneously, the others (3 students or $18.75 \%$ ) prefer to choose one method, either synchronous or asynchronous.

The reason for choosing the blended method are presented in Figure 2 below :

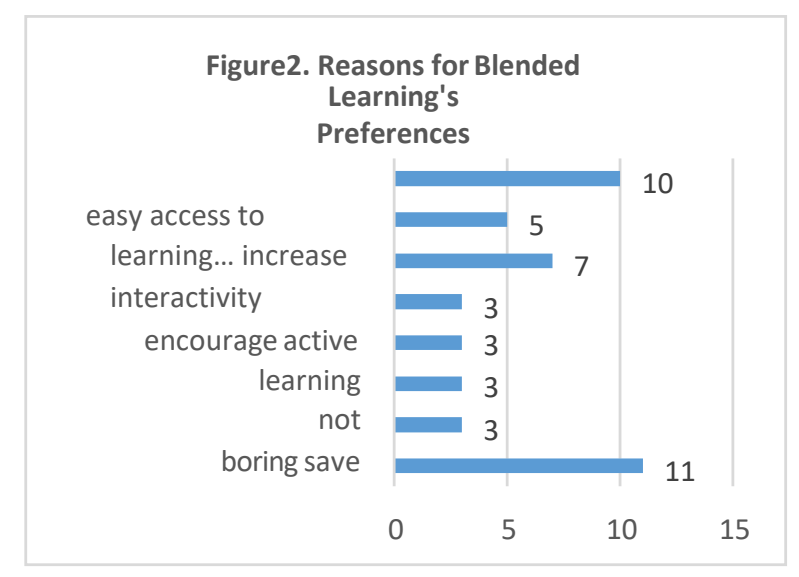

Figure 2 above shows that the two main reasons students prefer blended methods are easier to understand the topic discussed, and easy access to learning materials. Other reasons are encouraging active learning, increasing interactivity, not dull, saving internet quota, and being more flexible and motivated.

As previously described, four videos have been prepared for this class as an alternative way to explain the topic. The students also give a good response in this way. The following is the students' response to the video created.

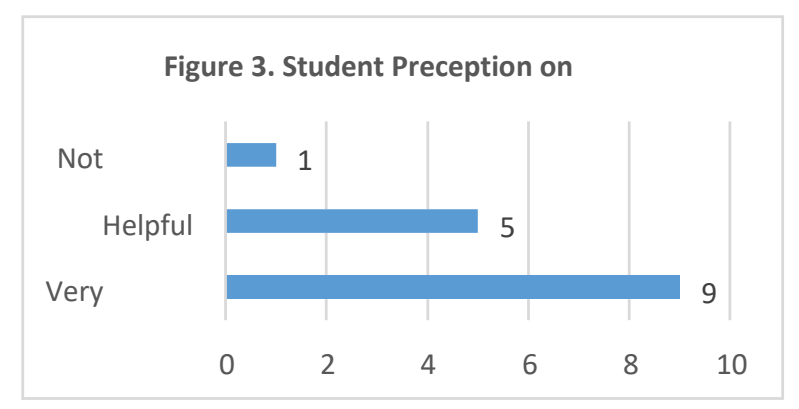

The figure above shows that most students said that the videos are beneficial (9 students or 56.25\%) and helpful (5 students or $31.25 \%$ ). Only one student that said the videos are not helpful for his/her learning activities. So, it can be concluded that the majority of students give positive responses to the blended method. Therefore, it is not surprising that all of the students highly confident ( 7 students or $43.75 \%$ ) and confident (9 students or $56.25 \%$ ) that they will pass Introduction to Accounting 1 with excellent grades, as presented in Figure 4 below: 


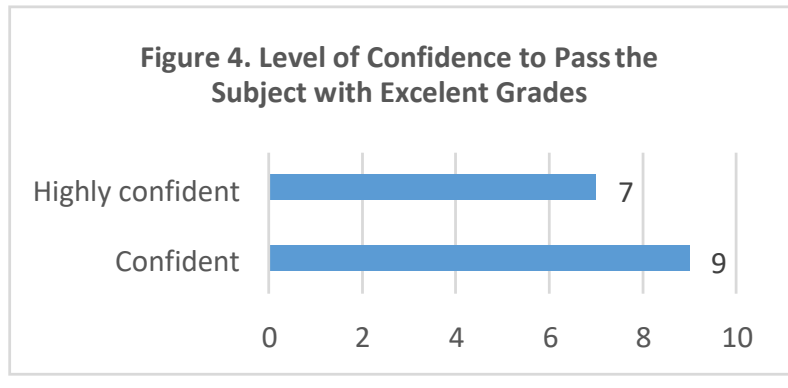

\subsection{The distribution of assignment score}

Besides student perception, the distribution of assignment scores is also used to evaluate blended learning methods. The following is the distribution of assignment score (on average) during half-semester:

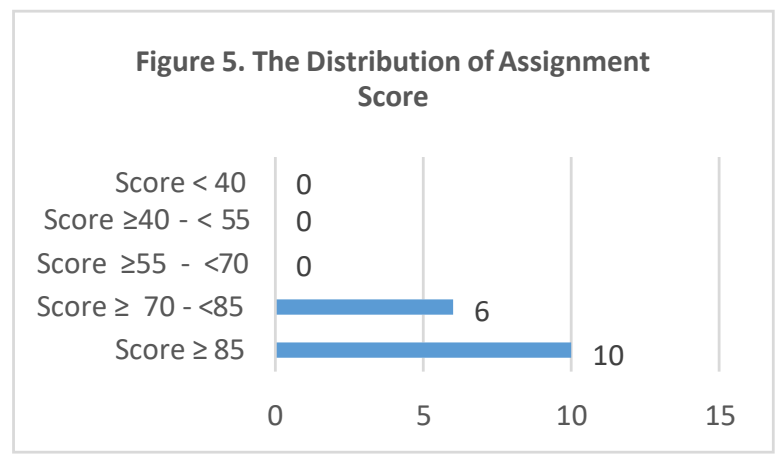

Figure 5 shows that ten students $(62.5 \%)$ get an average score of 85 and more, while six students (37.5\%) get an average score between 70 and 85 . None of them get an average score below 70 . These results confirm the student perception result (as described in Figure 4).

\subsection{The achievement of learning outcomes.}

In this study, the achievement of learning outcomes is also used to evaluate the blended method implementation. The achievement of learning outcomes is measured by a formative assignment through quizzes and group assignments. Based on the evaluation, the average score for the formative assignment also shows a good result.

\section{CONCLUSION}

Three indicators are used to evaluate the implementation of blended learning on Introduction to Accounting 1, which are (1) the student perception of this method (2) the distribution of assignment score (3) the achievement of learning outcomes. Based on student perception, it shows that most students prefer to use the blended method rather than others. Four main reasons of their preferences are easier to understand the topics, easy access to learning material, encourage active learning and increase interactivity.

The result also shows that all of them have high confident to pass the subject with excellent grades. This condition is also supported by their average assignment scores, which shows that they all get average scores between 70 to 100 . Therefore, based on the explanation above, it can be concluded that the implementation of blended learning on Introduction to Accounting 1 has been running well and shows satisfactory results.

\section{ACKNOWLEDGMENTS}

This work was supported by Lembaga Pengembangan Pendidikan dan Penjaminan Mutu (LP3M) Universitas Andalas and Accounting Department Economic Faculty, Universitas Andalas, Padang, West Sumatera.

\section{REFERENCES}

[1] Graham, C. R. (2006). Blended learning systems. The handbook of blended learning: Global perspectives, local designs, 3-21.

[2] Singh, H. (2003). Building effective blended learning programs. Educational Technology-Saddle Brook Then Englewood Cliffs NJ-, 43(6), 51-54. 